\title{
PENTINGNYA KETEPATAN DIAGNOSA KEPERAWATAN DALAM KEBERHASILAN ASUHAN KEPERAWATAN
}

\author{
Winda Sari Sinaga \\ windasarisng1701@gmail.com
}

\section{Latar Belakang}

Asuhan keperawatan menjadi suatu rangkaian proses pada praktik keperawatan yang wajib diberikan secara langsung kepada klien atau pasien. Asuhan keperawatan dilakukan berdasarkan ilmu pengetahuan dan kaidah-kaidah keperawatan yang bersifat humanistik dan berdasarkan kebutuhan objektif klien. Tujuan dari pelaksanaan asuhan keperawatan kepada klien ialah untuk mengatasi masalah yang sedang dihadapi klien.

Asuhan keperawatan berfungsi sebagai standar dan pedoman dalam pelaksanaan praktek keperawatan agar sesuai dengan nilai-nilai professional, etika keperawatan dan menuntun perawat agar mampu bertanggung jawab atas setiap tindakan yang dilakukan. Dalam tahapan asuhan keperawatan, terdapat tahapan diagnosa keperawatan yang merupakan salah satu tahapan penting dalam pelayanan asuhan keperawatan terhadap pasien. Tahapan diagnosa dilakukan apabila perawat sudah terlebih dahulu melakukan tahapan pengkajian sebagai dasar untuk dapat menentukan diagnosa keperawatan. Diagnosa keperawatan menjadi penilaian dan keputusan klinis yang dilakukan perawat tentang respons individu, keluarga, atau komunitas terhadap masalah kesehatan atau proses kehidupan aktual ataupun potensial sebagai dasar tahapan asuhan keperawatan selanjutnya, yaitu pemilihan intervensi keperawatan.

Tahapan Diagnosa keperawatan menjadi salah satu tahapan dimana perawat menerapkan ilmu dan pengetahuannya untuk dapat menetapkan diagnosa pasien dan menegakkan diagnosa keperawatan. Dimana berdasarkan pendidikan dan pengalamannya, perawat secara akuntabilitas dapat mengidentifikasi dan memberikan intervensi secara pasti untuk menjaga, menurunkan, membatasi, mencegah dan merubah status kesehatan klien. Tahapan diagnosa menjadi tahapan terpenting setelah melakukan pengkajian, perawat tidak dapat membuat dan menerapkan suatu rencana keperawatan tanpa menetapkan diagnosa pasien terlebih dahulu. Semua data yang 
didapatkan dari tahapan pengkajian keperawatan, diperlukan untuk merumuskan diagnosa keperawatan pasien. Setelah diagnosa sudah ditetapkan, maka selanjutnya perawat dapat membuat suatu rencanaan keperawatan. Perencanaan merupakan petunjuk tertulis yang menggambarkan secara tepat mengenai rencana tindakan yang akan dilakukan terhadap pasien sesuai dengan tingkat kebutuhan pasien berdasarkan diagnosa keperawatan yang telah di susun. Rencana keperawatan dibuat berdasarkan diagnosa yang telah dirumuskan dan ditetapkan. Tidak hanya itu, keberhasilan perencanaan keperawatan ditentukan dengan ketepatan perawat dalam menentukan dan menetapkan hasil diagnosa pasien. Maka dari itu, ketepatan perawat dalam menentukan dan menegakkan diagnosa keperawatan pasien sangat penting pengaruhnya untuk keberlangsungan serangkaian proses asuhan keperawatan selanjutnya.

\section{Metode}

Metode yang digunakan oleh penulis dalam jurnal ini adalah Literature review, dengan cara membaca, menganalisis bahan kajian yang relavan dengan pokok bahasan yaitu pentingnya ketepatan diagnosa keperawatan dalam keberhasilan asuhan keperawatan.

Dimana dengan membaca beberapa jurnal dan bahan kajian terkait lainnya, kemudian menyusun kalimat sendiri yang selanjutnya dituliskan untuk menyelesaikan literature review ini. Bahan kajian yang digunakan yakni berupa textbook, e-book, buku pedoman terkait, tesis dan jurnal online. Adapun jurnal dan referensi yang digunakan pada literature review ini, diterbitkan paling lama tahun 2012, dengan jumlah minimal yaitu 10 referensi.

\section{Hasil}

Berdasarkan hasil dari pencarian dan pengkajian literature dari berbagai sumber, didapatkan bahwa perawat memiliki masalah dalam menentukan dan menegakkan diagnosa keperawatan sesuai standar diagnosa keperawatan; adanya pengaruh pengetahuan perawat dengan ketepatan diagnosa yang dibuat; pengaruh masa kerja atau pengalaman, sikap, perilaku dan motivasi perawat juga menentukan hasil dari diagnosa yang ditetapkan dan kesalahan terkait selama pelaksanaan tahapan pengkajian. 
1). Perawat kesulitan dalam menentukan diagnosis keperawatan dan menetapkan diagnosa secara spesifik terkait keluhan dan masalah yang dialami oleh pasien.

Dari Jurnal Identifikasi Diagnosis Keperawatan Pada Pasien Di Ruang Paru Sebuah Rumah Sakit (2015), dan dari jurnal Kinerja Perawat dalam Penerapan Standar Asuhan Keperawatan di Rumah Sakit Umum Daerah Naibonat Kabupaten Kupang (2014), dari hasil kedua penelitian didapatkan bahwa perawat sering kali tidak menerapkan dan tidak melaksanakan prosedur asuhan keperawatan secara berurut atau sama sekali tidak memberikan asuhan keperawatan kepada pasien. Pada perawat yang melakukan proses asuhan keperawatan tidak sesuai dengan tahapan dan urutanya mengalami kesulitan melaksanakan tahapan asuhan keperawatan selanjutnya. Terutama apabila kesalahan terjadi pada tahapan pengkajian awal, maka dalam tahapan asuhan keperawatan selanjutnya akan semakin sulit untuk dilakukan, hal ini juga menjadi dasar perawat tidak melakukan asuhan keperawatan yang baik kepada pasien. Pada penelitian lainnya, perawat sering sekali merasa kesulitan dalam hal menetapkan diagnosa keperawatan yang tepat bagi pasien karena data dikumpulkan perawat tidak selaras dan belum meluas untuk dapat menetapkan suatu diagnosa. Perawat juga mengumpulkan data yang mempunyai relevansi atau kecocokan yang rendah dengan diagnosa keperawatan tertentu, sehingga diagnosa yang dibuat kurang spesifik. Selain hal-hal diatas banyak hal lainnya yang menjadi faktor pendukung perawat kesulitan dalam menegakkan hasil diagnosanya, seperti lainnya yaitu pengaruh pendidikan dan pengetahuan perawat, pengkajian dasar yang kurang tepat dan keterbatasan perawat.

2). Kesalahan terkait selama pelaksanaan tahapan pengkajian

Dari Jurnal Identifikasi Diagnosis Keperawatan Pada Pasien Di Ruang Paru Sebuah Rumah Sakit (2015), jurnal Kinerja Perawat dalam Penerapan Standar Asuhan Keperawatan di Rumah Sakit Umum Daerah Naibonat Kabupaten Kupang (2014), jurnal Diagnosa Keperawatan Yang Sering Ditegakkan Perawat Pada Pasien Tuberkulosis Paru di Rumah Sakit. Jurnal Kepemimpinan Dan Manajemen Keperawatan (2018), jurnal Pengembangan Instrumen Penegakan Diagnosis Keperawatan Pada Pasien Congestive Heart Failure (Chf) Berbasis Standar Diagnosis Keperawatan Indonesia (Sdki) (2018), dari hasil penelitian jurnal-jurnal diatas dijabarkan bahwa pengkajian keperawatan yang tidak terstruktur dengan baik. Pengalaman menunjukkan bahwa tingkat kesalahan pada tahapan pengkajian menjadi penyebab utama 
kesalahan penegakan diagnosa dan tahapan asuhan keperawatan selanjutnya. Pelaksanaan asuhan keperawatan yang dilakukan oleh perawat tidak mempunyai urutan yang runut dan terkait dengan diagnosis keperawatan. Perawat memandang tahapan pengkajian rendah tidak terlalu penting, sehingga banyak kesalahan dan kendala dalam merumuskan diagnosa masalah pasien. Perawat kerap kali tidak menjalankan tugasnya sesuai dengan standar prosedur tindakan sehingga tindakan yang dilakukan tidak runut atau tidak mempunyai urutan yang efektif dan terstruktur yang tentunya menjadi akar masalah untuk melanjutkan tahapan tindakan selanjutnya.

3). Pengaruh pengetahuan, masa kerja, sikap, perilaku dan motivasi perawat dengan ketepatan diagnosa yang dibuat.

Dari jurnal Pengaruh Pelayanan Asuhan Keperawatan Terhadap Kepuasan Pasien di Puskesmas Takalala Kabupaten Soppeng (2018), jurnal Gambaran Tingkat Pengetahuan Perawat dalam Penerapan Standar Asuhan Keperawatan di Ruangan Rawat Inap Interna RSUD Datoe Bhinangkang (2015) dan jurnal Faktor - Faktor Yang Berhubungan dengan Penerapan Standar Asuhan Keperawatan Di Ruang Rawat Inap RSUD Labuang Baju Makassar (2013), dari hasil penelitian jurnal-jurnal diatas dijelaskan bahwa adanya pengaruh dan hubungan yang signifikan terkait pengetahuan dan pendidikan perawat dengan keberhasilan dari proses asuhan keperawatan yang dilakukan oleh perawat ditempat kerjanya. Perawat yang memiliki pengetahuan yang baik atau perawat dengan keinginan belajar yang tinggi dan mau untuk belajar secara terus-menerus, akan mempengaruhi tingkat pengetahuan perawat yang yang selanjutnya akan mempengaruhi kualitas tindakan dan pelayanan yang diberikan perawat terhadap pasien.

Tindakan dan pelayanan yang diberikan perawat berkaitan erat dengan Asuhan Keperawatan yang diberikan kepada pasien, semakin perawat memahami setiap langkah dan tahapan prosedur asuhan keperawatan dan mau untuk menerapkan dalam setiap kali tindakan kepada pasien maka semakin tinggi nilai presentase kemungkinan Asuhan Keperawatan yang dilakukan berhasil. Faktor lainnya pada pengalaman perawat yang menunjukkan bahwa pengkajian yang dilakukan oleh perawat yang lebih berpengalaman, hasil pengkajian yang didapatkan lebih baik dari perawat dengan pengalaman yang rendah. Hasil pengkajian yang baik akan sangat membantu dari ketepatan diagnosa yang akan ditetapkan. 


\section{Pembahasan}

Diagnosa keperawatan merupakan suatu tahapan dalam proses keperawatan yang menggambarkan status kesehatan secara aktual, yang didalamnya tercakup penilaian klinis terhadap pengalaman/respon individu, keluarga, atau komunitas pada masalah kesehatan/risiko masalah kesehatan atau pada proses kehidupan. Diagnosis keperawatan menjadi hasil akhir dari pengkajian yang dirumuskan atas dasar interpretasi atau data dari hasil pengkajian yang telah dilakukan sebelumnya. Diagnosa keperawatan menjadi keputusan yang sudah ditetapkan, dirumuskan secara matang mengenai masalah yang dihadapi oleh pasien selama dilakukan perawatan dirumah sakit. Data pasien yang sudah didapatkan melalui tahapan pengkajian menjadi bahan dan dasar perawat dalam menentukan apa masalah keperawatan/diganosa keperawatan dan masalah kolaboratif/diagnosis potensial komplikasi yang dialami oleh pasien dan perawat selanjutnya membuat perencanaan dalam merawat pasien. Menurut Potter \& Perry (2009), penegakan diagnosis tidak berjalan dalam satu waktu tertentu saja, namun sepanjang waktu, format dan kualitas penegakan diagnosis dapat berkembang seiring waktu perawatan, tetapi fokusnya terus berdampak terhadap perawatan klien. Sistem penegakan diagnosis yang ideal harus memberikan informasi klien yang komprehensif, menunjukkan hasil dan standar klien, memfasilitasi reimbursement dari pemerintah dan dari perusahaan asuransi pembayar, serta berfungsi sebagai dokumen legal.

Dalam membuat dan menetapkan diagnosa keperawatan, perawat sering kali kesulitan dalam menetapkan suatu diagnosa bagi perawat. Pada dasarnya diagnosa keperawatan merupakan tahapan lanjutan dari tahapan awal dalam asuhan keperawatan, yaitu pengkajian keperawatan. Apabila kesalahan terjadi dimulai dari tahapan awal, maka sulit untuk mencapai hasil yang sesuai atau mengenai sasaran tindakan asuhan keperawatan yaitu fokus utamnya ialah kesembuhan pasien. Berdasarkan hasil penelitian pada sumber bacaan, pada praktek keperawatan kegiatan proses asuhan keperawatan tidak selalu dilakukan berurutan tetapi dikerjakan pada waktu bersamaan/tumpang tindih (overlapping). Hal ini menjadi salah satu penyebab perawat kesulitan menetapkan diagnosa keperawatan. Dalam penjelasannya, sering kali dalam perawat melakukan pengkajian keperawatan yang tidak tepat, tidak terstruktur dengan baik dan kurang meluas sehingga kekurangan data untuk dianalisa sebagai bahan penetapan diagnosa keperawatan yang sesuai. Pengalaman menunjukkan bahwa pengkajian yang dilakukan oleh perawat tidak 
mempunyai urutan yang runut dan terkait dengan diagnosis keperawatan. Sering terjadi perawat mempunyai data tertentu tetapi kebingungan untuk menentukan data tersebut mendukung diagnosis keperawatan yang mana. Atau sebaliknya perawat mempunyai prediksi pasien mempunyai diagnosis tertentu tetapi tidak tahu data apa yang perlu dikaji untuk mendukung diagnosis tersebut muncul. Maka dari hal itu penting bagi perawat untuk menjalankan tugasnya sesuai dengan standar operasional, sesuai dengan urutan dan tahapan proses keperawatan.

Seorang perawat harus perhatikan prioritas tertinggi yaitu masalah atau diagnosa keperawatan yang dapat bersifat mengancam kehidupan atau keselamatan pasien. Tidak semua masalah dapat diatasi secara bersamaaan, maka dari itu sangat diperlukan pengelompokan dan penentuan prioritas. Hirarki Maslow tentang kebutuhan dasar manusia menjadi pedoman dalam menentukan prioritas dengan memperperhatikan keluhan utama pasien. Selain itu juga masih terlihat penulisan rencana tindakan keperawatan yang tidak teratur dan kurang mengacu pada diagnosa keperawatan yang telah ditetapkan. Perumusan diagnosa keperawatan membutuhkan proses berpikir kritis, keterampilan penalaran dan pengalaman sebelumnya

Menurut hasil penelitian yang pertama yaitu dalam merumuskan diagnosis keperawatan harus terdapat beberapa kegiatan yang terlebih dahulu dilakukan seorang perawat sebagai penghantar antara tahapan pengkajian Keperawatan dengan diagnosa keperawatan. Terdapat beberapa kegiatan yang harus dilakukan dalam menetapkan diagnosa keperawatan pasien. Yang pertama, menginterpretasi dari data yang ada atau data dari hasil pengkajian yang telah dilakukan pada tahapan sebelumnya. Tindakan yang kedua yaitu melakukan verifikasi dengan pasien. Dan yang ketiga yaitu menentukan label diagnosis keperawatan serta menuliskan diagnosis keperawatan. Menurut Wilkinson (2007), apabila tindakan ketiganya telah dilakukan, selanjutnya perawat dapat menentukan, menyusun dan menetapkan rencana keperawatan yang sesuai dengan hasil diagnosa yang telah ditetapkan dan juga sesuai dengan kebutuhan pasien.

Persatuan Perawat Nasional Indonesia (PPNI), berkewajiban untuk menyusun berkewajiban untuk menyusun standar - standar yang meliputi standar kompetensi, standar asuhan keperawatan, dan standar kinerja profesional. Standar asuhan keperawatan dibutuhkan Standar Diagnosis Keperawatan, oleh karena PPNI menerbitkan Standar Diagnosis Keperawatan Indonesia (SDKI). Menurut Effendy (1995), perumusan diagnosa keperawatan yang baik ialah diagnosa yang 
harus dapat menggambarkan komponen problem, etiologi, symptom dan sign, serta harus berdasarkan kesenjangan antara status kesehatan normal dengan pola fungsi kebutuhan pasien.

Komponen pertama yang harus terdapat di dalam diagnosa keperawatan yaitu problem $(\mathrm{P})$, menurut pernyataan di dalam standar NANDA, umumnya problem merupakan masalah yang dialami pasien dan kebutuhan pasien yang tidak terpenuhi dengan baik. Komponen kedua ialah etiologi ( E), merupakan suatu studi yang mempelajari tentang penyebab atau faktor risiko atau penyebab terjadinya gangguan kesehatan pasien. Komponen ketiga yaitu Symptom dan sign (S), merupakan karakteristik atau tanda dan gejala yang didata dalam pengkajian untuk mendukung diagnosa keperawatan. Ketiga komponen diatas harus terdapat dalam diagnosa yang ditetapkan, sebagai dasar dari hasil diagnosa keperawatan. Dan dalam merumuskan diagnosa keperawatan yang tepat, dibutuhkan kemampuan analisis yang tinggi sehingga diperlukan sumber daya manusia yang capable dan mempunyai motivasi kuat untuk maju serta berpandangan maju (futuristic).

Dalam menetapkan diagnosa keperawatan haruslah sesuai dengan urutan dan tahapan serta mengandung komponen - komponen dasar yang membangun hasil dari diagnosa keperawatan. Langkah pertama dalam menentukan diagnosa keperawatan yaitu mengklarifikasi dan menganalisa data. Pada tahapan ini perawat menentukan, mengelompokkan dan memeriksa serta memastikan bahwa data yang digunakan sebagai dasar dari diagnosa merupakan data yang valid, benar, tepat dan jelas. Pada tahapan ini juga perawat memahami dan menganalisa ulang data yang ada seperti data subjektif, data fokus dan data objektif perawat harus mampu untuk mengaitkan setiap data yang dimiliki untuk selanjutnya perawat dapat menetapkan asuhan keperawatan terutama menentukan diagnosa keperawatan.

Langkah kedua yaitu penafsiran data. Dalam tahapan ini perawat harus mampu untuk memahami data pasien secara berkesinambungan satu dengan yang lainnya. Perawat harus mampu menentukan apa yang menjadi masalah pasien, membandingkan dengan data masalah kesehatan pasien sebelumnya, dan memutuskan penetapan diagnosa yang sesuai dengan masalah pasien. Contohnya gangguan pertukaran gas.

Langkah yang ketiga yaitu validasi data. Pada tahapan ini perawat mempertimbangkan yaitu kelengkapan data dasar yang akurat, data subjektif dan data objektif. Pertimbangkan kembali hipotesa yang sudah dibuat, karena dalam menentukan diagnosa keperawatan harus sesuai dengan ilmu pengetahuan atau ilmu keperawatan. Melalui tahapan validasi data ini perawat memastikan 
kembali keakuratan diagnosa yang telah dibuat atau diagnosa sementara. Langkah yang keempat yaitu perumusan diagnosa. Pada tahapan ini hasil diagnosa sudah final dan harus sesuai dengan standar diagnosa keperawatan. Setelah perawat mampu untuk menentukan diagnosa keperawatan langkah selanjutnya yaitu perawat menyusun diagnosa keperawatan yang sesuai dengan hasil diagnosa keperawatan yang sudah ditentukan. Adapun tahapan dalam menyusun diagnosa keperawatan yaitu yang pertama menuliskan masalah kesehatan pasien, diikuti atau disertai dengan penyebab masalah pasien, karakteristik dan gejala yang dialami pasien. Selanjutnya yang kedua yaitu menuliskan atau mencatat keadaan atau gangguan apa yang dialami pasien disertai dengan hal-hal yang diharapkan dari pasien. Dalam menyusun diagnosa keperawatan perlu diperhatikan tata bahasa dan istilah - istilah yang dituliskan perawat tidak boleh bersifat vonis, karena sifat dari diagnosa yang dibuat oleh perawat masih dapat diubah seiring perkembangan pasien.

Dalam sumber lainnya, adanya pengaruh diagnosa terhadap kepuasan pasien selama perawatan di rumah sakit. Dari hasil penelitian didapatkan bahwa hasil diagnosa berpengaruh negatif dan signifikan terhadap kepuasan pasien, hal ini menjelasakan bahwa semakin lengkap, keakurat dan jelas penjelasan tentang diagnosa keperawatan maka kepuasan pasien akan semakin menurun. Hal ini disebabkan karena diagnosa keperawatan/ masalah kesehatan merupakan salah satu stressor pasien. Dari data hasil nilai penelitian, rata-rata jawaban dari responden secara umum apabila mengenai diagnosa yang disampaikan menyebabkan tingkat stressor pasien berada pada level sangat tinggi. Hal ini terlihat pada nilai indikator yaitu actual, risiko atau resiko tinggi, kemungkinan, sejahtera, syndrome, yang masuk pada kategori sangat tinggi.

Dari hasil penelitian sumber lainnya dijelaskan bahwa adanya pengaruh pengetahuan dan pendidikan perawat dengan keberhasilan dari proses asuhan keperawatan yang dilakukan oleh perawat ditempat kerjanya. Diagnosis keperawatan telah diterapkan di berbagai institusi pelayanan kesehatan seperti rumah sakit dan fasilitas kesehatan lainnya, namun pengetahuan perawat terkait indikator-indikator diagnostik untuk penegakan diagnosis masih perlu ditingkatkan agar penegakan dapat dilakukan secara tepat dan terstandarisasi, serta proses penegakan diagnosisi tidak dianggap sulit. Tanpa terminologi dan indikator yang terstandarisasi, penegakan diagnosis keperawatan menjadi tidak seragam, tidak akurat dan ambigu sehingga menyebabkan ketidaktepatan pengambilan keputusan dan ketidaksesuaian asuhan keperawatan yang diberikan 
kepada klien. Maka dari hal tersebut, ada beberapa hal yang dapat dilakukan manajemen rumah sakit untuk pengembangan tingkat mutu pelayanan kesehatan yang diberikan yaitu perlunya pemberian sosialisasi dan penambahan pengetahuan perawat mengenai penegakkan diagnosis keperawatan berdasarkan NANDA-ISDA misalnya melalui program pelatihan penerapan asuhan keperawatan yang menekankan mengenai standar diagnosa keperawatan. Melalui sosialisasi mengenai penegakkan diagnosis keperawatan diharapkan mutu pelayanan yang diberikan perawat meningkat dan tentunya meningkatkan mutu dari rumah sakit tersebut.

Tindakan dan pelayanan yang diberikan perawat berkaitan erat dengan Asuhan Keperawatan yang diberikan kepada pasien, semakin perawat memahami setiap tahapan prosedur asuhan keperawatan dan menerapkannya maka semakin tinggi nilai presentase kemungkinan keberhasilan asuhan keperawatan yang dilakukan. Perawat yang memiliki pengetahuan yang baik atau perawat mengenai standar diagnosa keperawatan menunjukan ketepatan hasil diagnosa pada tingkat kategori yang tinggi. Perawat dalam masa pendidikan dipandang masih dalam proses pendidikan, memiliki keinginan belajar yang tinggi untuk belajar secara terus-menerus, akan mempengaruhi tingkat pengetahuan perawat yang yang selanjutnya akan mempengaruhi kualitas tindakan dan pelayanan yang diberikan perawat terhadap pasien juga mempengaruhi hasil dari ketepatan diagnosa yang telah ditentukan. Faktor lainnya pada pengalaman perawat yang menunjukkan bahwa pengkajian yang dilakukan oleh perawat yang lebih berpengalaman, hasil pengkajian yang didapatkan lebih baik dari perawat dengan pengalaman yang rendah. Hasil pengkajian yang baik akan sangat membantu dari ketepatan diagnosa yang akan ditetapkan.

\section{Penutup}

Penegakan diagnosa keperawatan merupakan tanggung jawab penuh perawat, penentuan keputusan diagnosa keperawatan haruslah mampu untuk meningkatkan status kesehatan pasien secara bertahap dan diharapkan berhasil meningkatkan pola hidup sehat pasien selanjutnya. Penentuan diagnosa keperawatan harus berdasarkan standar diagnosa keperawatan dan dalam

pelaksanaannya haruslah dilakukan secara bertahap dan berurut, untuk menghasilkan diagnosa keperawatan yang tepat dan sesuai dengan masalah dan kebutuhan pasien.

Ketepatan diagnosa keperawatan penting sebagai tahapan lanjutan untuk merencanakan, membuat dan menentukan intervensi keperawatan. Perawat harus melakukan proses asuhan 
keperawatan secara baik, bertahap dan sesuai dengan standar diagnosa keperawatan agar perawat tidak lagi mendapatkan masalah atau kesulitan dalam menentukan diagnosa keperawatan yang sesuai dengan masalah kesehatan pasien.

\section{Daftar Pustaka}

Apriyani, H.. 2015. Identifikasi Diagnosis Keperawatan Pada Pasien Di Ruang Paru Sebuah Rumah Sakit. Jurnal Keperawatan. 6(1) : 107-111.

Cikwanto dan Nupiyanti. 2018. Pengembangan Instrumen Penegakan Diagnosis Keperawatan Pada Pasien Congestive Heart Failure (Chf) Berbasis Standar Diagnosis Keperawatan Indonesia (Sdki). Jurnal Keperawatan Aisyiyah (JKA). 5(1).

Dahmhudi, D., Irawaty, D., Hariyati., T., S. 2012. Efektifitas Metode NIHSS Dan ESS Dalam Membuat Diagnosa Keperawatan Aktual Pada Pasien Stroke Berat Fase akut. Jurnal Keperawatan Indonesia, 15(1), 8-12.

Nogo, Antonia. 2014. Kinerja Perawat dalam Penerapan Standar Asuhan Keperawatan di Rumah Sakit Umum Daerah Naibonat Kabupaten Kupang. Jurnal Penelitian. 18(1): 62-66.

Rofi, M., Warsito., B., E., Santoso., A., dkk. 2018. Diagnosa Keperawatan Yang Sering Ditegakkan Perawat Pada Pasien Tuberkulosis Paru di Rumah Sakit. Jurnal Kepemimpinan Dan Manajemen Keperawatan. 1(2) : 2-8.

Bumulo, Mohammad Iqbal, Hendro Bidjuni, \& Jeavery Bawotong. 2017. Pengaruh Manajemen Model Asuhan Keperawatan Profesional Tim Terhadap Kualitas Pelayanan Keperawatan di Bangsal Pria RSUD Datoe Binangkang Kabupaten Bolaang Mongondow. e-Jurnal Keperawatan. $5(2)$.

Achmadi, L. D., Pondaag, L., \& Babakal, A. 2015. Gambaran Tingkat Pengetahuan Perawat dalam Penerapan Standar Asuhan Keperawatan di Ruangan Rawat Inap Interna RSUD Datoe Bhinangkang. Jurnal Keperawatan. 3 (3): 1-3. 
Astar, Fatmawati, dkk. 2018. Pengaruh Pelayanan Asuhan Keperawatan Terhadap Kepuasan Pasien di Puskesmas Takalala Kabupaten Soppeng. Journal stieamkop MIRAI : JOURNAL OF MANAGEMENT. 1 ( 2) : 33-57.

Nurlina, dkk. 2013. Faktor - Faktor Yang Berhubungan dengan Penerapan Standar Asuhan Keperawatan Di Ruang Rawat Inap RSUD Labuang Baju Makassar. Journal Univeristas Negri Makassar. 7 ( 4 ).

Simamora, R. H., Bukit, E., Purba, J. M., \& Siahaan, J. (2017). Penguatan kinerja perawat dalam pemberian asuhan keperawatan melalui pelatihan ronde keperawatan di rumah sakit royal prima medan. Jurnal pengabdian kepada masyarakat, 23(2), 300-304.

Simamora, R. H. (2019). Socialization of Information Technology Utilization and Knowledge of Information System Effectiveness at Hospital Nurses in Medan, North Sumatra. Editorial Preface From the Desk of Managing Editor..., 10(9).

Rachmania, D.. 2016. Pengembangan Instrumen Penegakan diagnosis Keperawatan Berbasis SDKI Penelitian Action Research Di Ruang Teratai RSUD AM Pare Kediri. Thesis .Universitas Airlangga. 